\title{
THE FRAMING OF LGBT ISSUES ON NEWS PORTAL MEDIA IN MALAYSIA
}

\author{
Kok Jean Jie ${ }^{1}$ \\ Master of Science, Faculty of Modern Languages and Communication, Universiti Putra Malaysia. \\ (Email: jean98jie@outlook.com) \\ Dr Julia Wirza Mohd Zawawi ${ }^{2}$ \\ Department of Communication, Universiti Putra Malaysia. \\ (Email: wirza@upm.edu.my) \\ Assoc. Prof. Dr Akmar Hayati Ahmad Ghazali ${ }^{3}$ \\ Department of Communication, Universiti Putra Malaysia. \\ (Email: akmar@upm.edu.my)
}

Received date: $25-11-2019$

Revised date: 19-12-2019

Accepted date: $23-12-2019$

Published date: 29-12-2019

To cite this document: Kok, J. J., Zawawi, J. W. M., \& Ghazali, A. H. A. (2019). The Framing of LGBT Issues on News Portal Media in Malaysia. International Journal of Law, Government and Communication, 4(17), 102-120.

DOI: $10.35631 / \mathrm{ij} \operatorname{lgc} .4170011$

Abstract: LGBT has been prohibited in Malaysia and been stated by Prime Minister of Malaysia on 21 st September 2018. It becomes one of the top concerns news in Malaysia that faced legal and social challenges from the political aspect and society. The news of the LGBT issues had been published to the public, especially on news portal media. This research aims to determine the concerns of journalists in the process of interpreting LGBT news by using news portal media in Malaysia. At the same time, this research also aims to identify the process of journalists to frame the LGBT news by using the frame-building process affected by internal and external factors. In order to meet objectives, the researcher will analyses the effect of the factors on the news framing of LGBT issues through news portal media in the perceptive of journalism. Framing theory is the main theory that will be used in this research. The researcher will adapt and adopt the framing theory of De Vreese (2005), mainly focus on the frame-building process. At the same time, the researcher will examine the most significant internal and external factors found in the framebuilding process which mainly affected in the process of interpreting LGBT issues on news portal media in Malaysia. For the data analysis and findings of this research, the researcher will use content analysis to show out the results by using the codebook. Online news articles about LGBT issues on news portal media of Malaysia such as Malaysiakini and The Star will be filtered and coded in the codebook. This research has delivered valuable insights into the field of journalism in framing different aspects of news.

Keywords: Framing; Frame-Building; LGBT; News Portal Media 


\section{Introduction}

New media such as news portal media, social media and mobile applications became salient as the rapid growth of technology in the world. Communication process among internet is the most ordinary mechanism by the area of digital applications' revolution such as computer and smart phone (Peckham, 2013). During the revolution of internet, new media has provided new opportunities of engaging in social interaction on the internet by merging the newest news to the public especially in the field of journalism. The development of journalism had changed regarding to the revolution of internet, from printed newspaper to news portal media. In this $21^{\text {st }}$ century, journalism is more rely on internet or new media which known as news portal media, due to the engagement with technology (Newman, 2019). Hence, news portal media plays a part of important tools for the public to retrieve news information. News publishers such as Malaysiakini, The Star, Sin Chew are focusing on online news, at the same time they also publishing printed newspaper.

One of the top concerned social news in Malaysia is about LGBT issues. Zurairi (2013) and Bhavan (2018) stated that LGBT issues become one of the top concern news in Malaysia as this issue related to the aspects of human right and lead to social and political issues. LGBT issues have been discussed by political individuals such as Prime Minister, from the past until now. This proved by the speech given by Prime Minister of Malaysia, Tun Mahathir bin Mohamad, in the press conference after the meeting of Cabinet Committee. At the same time, LGBT issues face legal and social challenges (Low, 2009; Shield, Cohen, Glassman, Whitaker, Franks \& Bertolini, 2012, Malaysiakini, 2012; The Star, 2018). Legal challenges happened because Malaysia laws and political aspects do not accept and protect individuals that involved in LGBT issues. Social challenges refer to the reactions from the public towards this event, especially the negative reactions as most of the public in Malaysia reject on LGBT issues.

The main influence on the LGBT issues comes from the perceptive of journalism (Gomillion \& Giuliano, 2011; Ayoub, 2018). Thus, journalists act as the important role for shaping and publishing the LGBT news. Journalists frame the news due to several factors (De Vreese, 2005). These factors may affect by the conditions that happening in society and even in the news management. This research desires to identify the factors and concerns of journalists in the process of interpreting LGBT news to the public by using new media or news portal media. At the same time, identifying the main factors that occurred the publication of news articles of LGBT issues in Malaysia although LGBT is prohibited in Malaysia. Hence, this research will focus on framebuilding process while constructing the news of LGBT. Researcher will analyse the internal and external factors that influence the process of framing LGBT news by the journalists in Malaysia. This research also aims to study and understand the limitation of news to the public.

In order to understand the relationship between news portal media and LGBT issues, the research will focus on the research question which is What are the main factors influencing the news of LGBT issues on news portal media? Followed by two sub research questions: What is the internal factor that affected on the process of framing LGBT news by using news portal media? What is the external factor that affected on the process of framing LGBT news by using news portal media? Overall, the objectives of this research are: To determine the factors that affect the framing process of LGBT issues on news portal media, in the perception of journalism, to identify the concerns on framing process of LGBT issues, from the internal factor, and to examine the concerns on framing process of LGBT issues, from the external factor. 
Selection of two major news portal media in Malaysia (Malaysiakini and The Star) as the sample of this research will be applied, from $9^{\text {th }}$ May 2018 to $30^{\text {rd }}$ November 2019 as it's the $14^{\text {th }}$ General Election of Malaysia and pilot test will be carried out. Malaysiakini is the first news publisher that offers the service of online news in Malaysia, provided 4 main languages of news articles and achieved the first rankings of news portal media while The Star achieved second top ranking among the news portals media in Malaysia that mainly offers news article in English only (Dinobeano, 2018 \& "Top Sites in Malaysia", 2018). Types of the online news article will be specialized and focused on the online news that related with LGBT issues only, by searching the keyword 'LGBT'. The selection for online news articles of this research are 100\% from the news publishers in Malaysia, hence, using the convenience sampling in the process to collect the data is needed. The codebook method will be conducted as the instrument of this research.

\section{Background of Theory}

Framing theory is the core theory in this research. Framing theory is the second level of agendasetting theory. The concept of framing theory is originally founded by Bateson in 1954. Bateson (1954) stated that the idea of framing has the power of influencing the process of thinking during interaction. Goffman (1974) stated that framing theory is the frame of social concept and framework which acknowledge the public to construct the experiences, involvements and practice. By using the frame, the public are able to identify, detect, notice and descript the progress of information. This process able frame concludes the environment in sociology, such as the environment of logics, concepts, understandings and also behaviors. In short, framing theory of Goffman studies is to identify and analyze the process of influencing in framing towards behavior.

Tuchman (1978) stated that the framing in the field of journalism is about the process of media appointed the frame to the public for having discussion on the events that happen in surrounding. Framing acts as the tool to limit the available of discussion for the public. Framing in journalism is also aims to expect the audience responses. Entman (1993) noticed that the elements involved in framing are selection and salience, which is the process of selective several conditions or attitudes of recognized reality as to create and generate the conditions or attitudes to be more important in the context of communication. Entman (1993) mentioned that this concept is essential in the communication process of describing problems, evaluating and also recommending for the selected conditions or attitudes.

Semetko and Valkenburg (2000) specified that there are five new frames in framing theory, which are responsibility, conflict, human interest, economy consequences and morality. Responsibility frames are the situations that who should be responsible on the impacts of the news framing. The result or cause of this responsibility frames should concern by and based on specific individuals or groups, either it is responsible by private controls or political controls. Conflict frame refers to the conflict or disagreement that arises between individuals or groups. Human interest frame assigns the issues presented from the angle of emotional. Economy consequences mentioned on the framing process on some issues that related in the field of economy and affected on individuals or groups. Morality frame is regarding to the issues are presented or framed from the perception of religious or moral which is less adapted by journalists.

Framing is also one of the trademarks in the field of media (Raza, Kharal \& Bhatti, 2017). This is because framing is able to link audiences to selected agenda and reperform and reproduce the 
message of the information. By having framing as the tool of media, information can be conveyed through news articles. Sogelola (2018) mentioned that it is essential to take note on the audience's attitude change which engaged to be perceived by the audience. Su, Liu and School (2019) stated that four aspects involved in framing which are enhancing border integrity, preventing border related crimes, a form of xenophobia and rallying supporters. And also, two approaches that involving framing are drive by basic values, which known as value frame and strategy frame. In order to have strong perception on the framed issue, belief and influence play as the basic and important role in it.

In this research, researcher will adapt and adopt the framing theory of De Vreese (2005). According to De Vreese (2005), framing theory involves the communication process that introducing or declaring and descripting an argument or concern. Framing theory involves two stages which are frame-building and frame-setting. Frame-building is the factors that affect the fundamental qualities of new frame. It has two aspects which are internal and external aspects that influence the action of framing. In the study of De Vreese (2014), the researcher highlighted the significant of the communication between internal and external roles. Internal roles refer to media roles such as journalists and news management and also external roles such as strong and strategic audiences and communicators. The method of frame-building aims to identify how the journalist's ordinaries that act as news values and the interplay with external actors that act as sources edge to the development of strong and sensitive cultural frames.

Frame-setting is the second stage in the study of De Vreese (2005). Frame-setting is the interplay between media frames and audience's knowledge and perception. The result of framing relies on the audience's thinking, which is known as the feedback or effect of the audiences that been framed by the selected issue. Frame-setting aims to contribute the audiences with the journalist's own clarifications and interpretations of an issue. Strömbäck and Esser (2009) mentioned that framesetting can be explained as details of strong relation in media, in the act of intervening, by understanding the different methods during the stage of shaping news information. It is the consequence of a progress on mutual decision-making and sense-making within the newsroom and the agreement between journalists and the sources. Hence, the results are not same due to different reflections of the audiences. This research will apply frame-building as to determine to the process of journalists frame the LGBT news that affected by internal and external factors. The figure below is the integrated process model of framing in the study of De Vreese (2005).

Figure 1: The Integrated Process of Framing by De Vreese (2005).

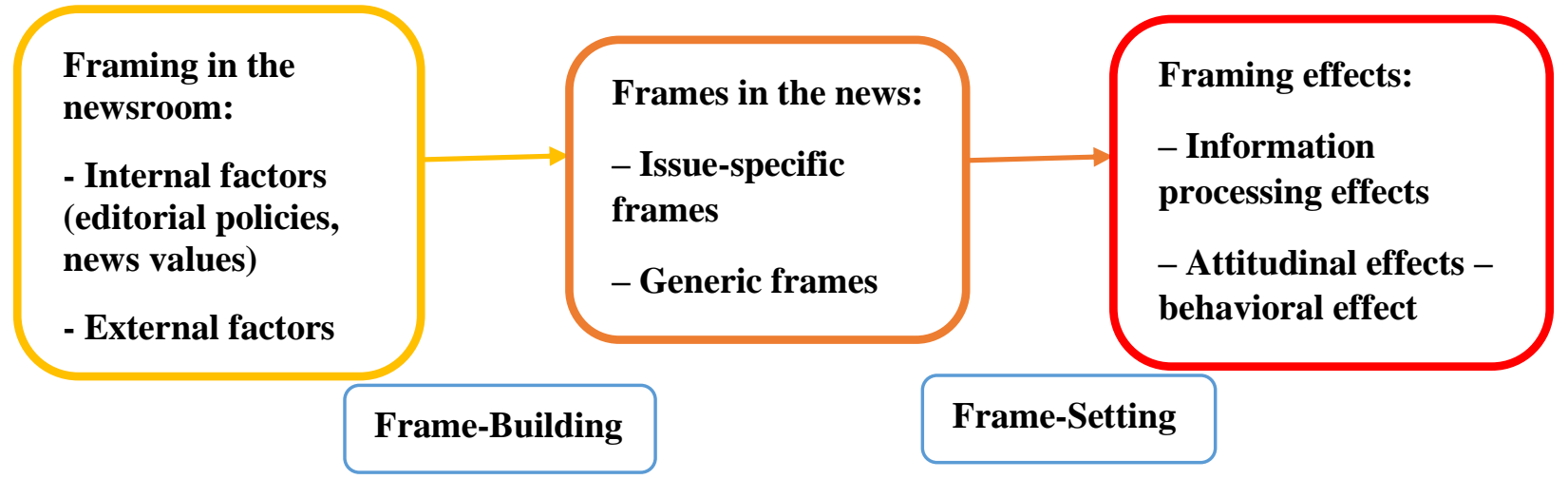

Source: (Integrated process by De Vreese, 2005, News Framing: Theory and Typology.) 
The internal and external factors that stated are the statements of understanding and clarification of the factors occurred on different issues and events at different places, hence this research paper aims to investigate which internal and external factors have the strongest impact on the process of framing for LGBT issues on news portal media in Malaysia. At the same time, to figure out the factors that is not merely depends on the development and happening of the issues or events, but also depends on the application and the use of the rules and regulations to such issues or events. Although the internal and external factors are different, hence, these factors are numerous aspects of closeness which is under the section of frame-building. The factors must have the capacities and characteristics to transmit information in order to achieve the basic communicating functions. This is because each factor must have the clear and direct way to function as the element that influence the result of framing on selected issues or events.

\section{Findings of Previous Studies}

This section reviews and analyses on the previous studies of selected parts in this research. Easterby-Smith, Thorpe and Lowe (2002) stated that previous studies have the capability to researchers in order to proceed the process of date collection, as previous studies act as the acceptable supporters of the research. In this research, researcher will adapt and adopt the framing theory of De Vreese (2005), mainly focus on frame-building process (internal and external factors), to identify the framing of LGBT issues on news portal media in Malaysia. This section stated out the support ideas of previous studies as the guideline of this research.

Journalism is the field of news writing that capable to influence and effect the mindset of the public globally (Mustaffa, Sannusi, Hasan \& Mat Saad, 2017). Journalists are the person that in charged in producing news articles, which also known as news writers. Deuze (2005) stated that journalists must have several attributes which are being ideology, providing public service, neutral, objective fair and credible, editorial autonomy, freedom and also independence. On the other hand, journalists must also have the feeling of immediacy, ethics and legitimacy. In this century, journalism is more rely on new media, especially on news portal media, Facebook pages and YouTube videos as well. This is because the rise of new media has powerful influences in the direction of news reports and news writing (Mustaffa, Sannusi, Hasan \& Mat Saad, 2017). Rajendran and Thesinghraja (2014) stated that new media becomes one of the basic elements in this modern lifestyle. New media acts as the main communication tool as it is more transparent and engaging with the public. News can transmit rapidly by using new media such as news portal media and social media. Hence, this research will only focus on the online news articles through news portal media in Malaysia.

As stated earlier, this research will determine the internal and external factors that has power influence and effects on the framing process of LGBT issues on news portal media in Malaysia. The internal factor will adopt from the framing theory of De Vreese (2005), which is editorial policies. Editorial policies act as the internal factor that to identify the process of journalists organizing and framing the issues. Le (2010) stated that editorial policies are the point to have deeper research as this aspect has own specific character in framing theory. Nord (2000) mentioned that editorial policies aim to study as to determine the role and political opinion-making. The study discussed the analysis and role of the editorials. The other internal factor is media roles and news values. In the study of Gorp (2010), researcher stated about news frames is the relationship with cultural beliefs with significant meaning among values, stereotypes, myths, narratives and 
archetypes. Values are shaped through myths and symbolized by archetypes. Archetypes are the aspects that build up the stories and stereotypes are the aspects of simplified features of a number of audiences. Hence, frame-building in media has the characteristic of having the process of producing cultural values and strong beliefs.

Government as the external factor as politic change has relationship to alter the framing process of journalists during conducting the LGBT news articles. According to De Vreese, Peter and Semetho (2001), most of the research studies proposed that news that related with the aspects of political and economy usually framed in terms of conflict or economic consequences (Semetko \& Valkenburg, 2000) of events, issues and policies. The research studies such as Graber (1988), Gamson (1992), Neuman, Just and Crigler, (1992) and also McManus (1994). Waheed, Schuck, Neijens and De Vreese (2015) stated that most of the public have less interests on political speech. This study mainly examines on political behaviors by moderating of values, in the details of changes on news frames and message sources. Meanwhile, the framing on news also represent the important concerns or issues that related to politic, at the same time boosting the public to have interests on it (Kinder, 2007). Lua, Mihalikb, Heerec, Mengb and Fairchildd (2019) stated that the feature affected media to form an event is from political element, which is the political tool that can be controlled by the social elites.

Besides that, cultural theme is also the external factor. In the growth of frame-building, by applying new values, journalists have to being concern on cultural themes which will change frequently while media frame is formed (Scheufele, 1999). Meanwhile, media frames that related with cultural themes have natural benefit that will occur above other types of frames. Edy and Meirick (2007) mentioned that personal experiences are also the factor that will influences frame-building process as not all the frames are connected continuously with external indications and explanations of cultural themes. Audiences has power of persuasive to resolve the selected issue. This result will occur in daily life, such as having the conversation within different audiences. Reese (2001) mentioned that the basic of framing research is based on the understanding of how people react and make sense on their personal experience.

\section{Conclusion}

In Malaysia, the LGBT community faces a lot of challenges as LGBT practices are regarded as illegal and socially unacceptable from perspective of religion (Muhammad, 2000 \& Malaysiakini, 2012). LGBT is one of the most controversial and sensitive issue in Malaysia as the nation leaders, from the past until now, have been taking a strong stand against it with no tolerance when it comes to LGBT rights. LGBT related news published on news media portal will be significant and susceptible to criticisms of public (Bendix, 2019). This research will show and explain how the internal and external factors of frame-building process affected effectively on LGBT issues towards Malaysians by providing the result of significant level. However, these factors may be criticized or evaluated that legally as 'right' or 'wrong' due to these previous studies are based on different issues and events. The descriptions of factors that proved previously may also be determined and examined that are these internal and external factors are suitable in the case of LGBT issues, from the perception of journalism in Malaysia. The aspects of factors, for both internal and external factors that stated should be investigated as linked to the selected issue which is LGBT issues, that published on news portal media in Malaysia. Expectation results of this research is a recognition of LGBT issues in news framing process. By clarifying the strongest 
influenced factors, both internal and external factors, researcher is able to contribute the better understanding of framing during publishing the news for selected and sensitive issues or events in the perceptive of journalism in Malaysia. The requiring of different factors in framing and the clear and direct explanations of relations in framing enable researcher to provide understandable and logic model as well.

\section{References}

Ayoub, P. M. (2018). How the Media Has Helped Change Public Views About Lesbian And Gay People? Retrieved from https://scholars.org/brief/how-media-has-helped-change-publicviews-about-lesbian-and-gay-people.

Bateson, G. (1954). A Theory of Play and Fantasy. New York: Ballantine.

Bendix, T. (2019). Does LGBT Media Have a Future? Retrieved from https://www.buzzfeednews.com/article/trishbendix/future-of-lgbt-media-out-advocateautostraddle-into-grindr.

Bhavan, J. (2018). In Mahathir's Malaysia, No Gay Rights and No Free Speech. Retrieved from https://www.scmp.com/week-asia/politics/article/2155228/mahathirs-malaysia-no-gayrights-and-no-free-speech.

De Vreese, C., H. (2005). News Framing: Theory and Typology. Journal of Information Design, 13 (1), 51-62.

De Vreese, C., H. (2014). Mediatization Of News: The Role of Journalistic Framing. In F. Esser, \& J. Strömback, (Eds.), Mediatization Of Politics: Understanding the Transformation of Western Democracies (pp. 137 - 155). Basingstoke: Palgrave Macmillan.

De Vreese, C., H., Peter, J., \& Semetho, H. (2001). Framing Politics at The Launch of The Euro: A Cross-National Comparative Study of Frames in The News. Journal of Political Communication, 18 (2), 107-122.

Deuze, M. (2005). What Is Journalism? Professional Identity and Ideology of Journalists Reconsidered. Journal of Journalism, 6 (4), 442-464.

Dinobeano. (2018). Congratulations to Malaysiakini - The No.1 News Portal in Malaysia. Retrieved from https://dinmerican.wordpress.com/2018/06/28/congratulations-toMalaysiakini-the-no-1-news-portal-in-malaysia/.

Easterby-Smith, M., Thorpe, R., \& Lowe, A. (2002). Management Research: An Introduction, $2 n d$ Edition. London: Sage Publications.

Edy, J. A., \& Meirick, P. C. (2007). Wanted, Dead or Alive: Media Frames, Frame Adoption, And Support for The War in Afghanistan. Journal of Communication, 57, 119 - 141.

Entman, R. (1993). Framing - Toward Clarification of a Fractured Paradigm. Journal of Communication, 43 (4). 51-58.

Goffman, E. (1974). Frame Analysis: An Essay on the Organization of Experience. New York: Harper and Row.

Gomillion, S. C., \& Giuliano, T. A. (2011). The Influence of Media Role Models on Gay, Lesbian, and Bisexual Identity. Journal of Homosexuality, 58 (3), 330-354.

Graber, D. A. (1988). Processing the News: How People Tame the Information Tide (2 ${ }^{\text {nd }}$ Edition). New York: Longman.

Kaos Jr, J. (2018, September 21). Dr M: M'sia Does Not Accept LGBT Culture, Same-Sex Marriage. The Star. Retrieve from https://www.thestar.com.my/news/nation/2018/09/21/msia-does-not-accept-lgbt-culturesame-sex-marriage/. 
Kinder, D. (2007). Curmudgeonly Advice. Journal of Communication, 57, 155-162.

Le, E. (2010). Editorials and The Power of Media: Interweaving of Socio-Cultural Identities. Philadelphia: John Benjamins Publication Company.

Low, W. Y. (2009). Malaysia Youth Sexuality: Issues and Challenges. Journal of Health and Translational Medicine, 12(1), 3-14. ISSN: 1823-7339.

Lua, Q., Mihalikb, B. J., Heerec, B., Mengb, F., \& Fairchildd, A. (2019). Media Effect on Resident Attitudes Toward an Olympic Bid. Journal of Tourism Management Perspectives, 29, 66 -75 .

Najib: No Place in Malaysia for LGBTs. (2012, June 6). Malaysiakini. Retrieved from http://www.malaysiakini.com/news/201913.

McManus, M. (1994). Market Driven Journalism: Let the Citizen Beware? Canada: Sage Publication.

Muhammad, S. (2000). Outlines of Criminal Law and Justice in Islam. Selangor, Malaysia: International Law Book Service.

Mustaffa, N., Sannusi, S. N., Hasan, A. S. A., \& Mat Saad, M. Z. (2017). Journalism and News Industry in Malaysia: New Media, New Challenges. E-Bangi Journal, 12 (2), 73-80.

Neuman, W. R., Just, M. R., \& Crigler, A. N. (1992). Common Knowledge: News and The Construction of Political Meaning. Chicago: University of Chicago Press.

Newman, N. (2019). Journalism, Media, and Technology Trends and Predictions 2019. United Kingdom: Reuters Institute for the Study of Journalism.

Nord, L. (2000). Vår Tids Ledare. En Studie Av Den Svenska Dagspressens Politiska Opinionsbildning (Our Leaders: A Study of The Swedish Daily Press's Political Opinion Formation). Stockholm: Carlssons.

Peckham, M. (2013). Could Nanowire Transistors Rescue Moore's Law from Obsolescence? Retrieve from: http://techland.time.com/2013/05/01/could-nanowire-transistors-rescuemoores-law-from-obsolescence/.

Rajendran, L., \& Thesinghraja, P. (2014). The Impact of New Media on Traditional Media. Journal of Scientific Research, 22 (4), 609-616.

Raza, S. H., Kharal, W. K., \& Bhatti, M. A. (2017). Attack on Malala: Framing of The Incident in The Print Media. VFAST Transactions on Education and Social Sciences, 12 (1), 1 - 7.

Reese, S.D. (2001). Prologue - Framing Public Life: A Bridging Model for Media Research. In S.D. Reese, O.H. Gandy and A.E. Grant (Eds.), Framing Public Life: Perspectives on Media and Our Understanding of The Social World (pp. 7-31). Mahwah, New Jersey: Lawrence Erlbaum Associates.

Scheufele, D. A. (1999). Framing as A Theory of Media Effects. Journal of Communication, 49 (1), $103-122$.

Semetko, H., \& Valkenburg, P. (2000). Framing European Politics: A Content Analysis of Press and Television News. Journal of Communication, 50 (2), 93-109.

Shield, J. P., Cohen, R., Glassman, J. R., Whitaker, K., Franks, H. \& Bertolini, I. (2012). Estimating Population Size and Demographic Characteristics of Lesbian, Gay, Bisexual, and Transgender Youth in Middle School. Journal of Adolescent Health, 52 (2), 248-250.

Sogelola, D. (2018). Brexit, Agenda Setting and Framing of Immigration in the Media: The Case of the Daily Mail. LSE Undergraduate Political Review, 1, 128 - 142.

Strömbäck, J., \& Esser, F. (2009). Shaping Politics: Mediatization And Media Interventionism. In K. Lundby (Eds.), Mediatization. Concept, Changes, Consequences (pp. 205-223). New York: Peter Lang. 
Su, M. H., Liu, J., \& School, D. M. M. (2019). Computers in Human Behavior Pathways to News Sharing: Issue Frame Perceptions and The Likelihood of Sharing. Journal of Computers in Human Behavior, 91, 201 - 210.

Top Sites in Malaysia. (2018). Retrieved from https://www.alexa.com/topsites/countries/MY.

Tuchman, G. (1978). Making News: A Study in The Construction of Reality. New York: Free Press. Van Gorp, B. (2010). Strategies to Take Subjectivity Out of Framing Analysis. In P. D'Angelo, \& J. A. Kuypers, (Eds.), Doing News Framing Analysis: Empirical and Theoretical Perspectives $(84-109)$. New York: Routledge.

Waheed, M., Schuck, A., Neijens, P., \& De Vreese, C., H. (2015). The Effects of News Frames and Political Speech Sources on Political Attitudes: The Moderating Role of Values. Journals of Communication, 40 (2), 147-169.

Zurairi, A. R. (2013). Beware of LGBT and Freedom of Religion Movements. Retrieved from http://www.themalaysianinsider.com/malaysia/article/shun-fatwas-from-politiciansmuhyiddin-tells-muslims. 